\title{
Invisible Strings: Exploring Connections Between the Poetries of Jean Valentine and Meta Kušar
}

Barbara Siegel Carlson

FLS International, 131 Tremont Street \#400, Boston, MA 02111, USA

bsiegelcarlson@gmail.com

The epigraph in poet Jean Valentine's book Break the Glass: "A pencil/for a wing bone" (by Lorine Neidecker) leads us to consider the way writing allows for transcendence. Similarly, in her work, Meta Kušar brushes out stars with a comb and then finds "an accomplice / combed / in this hollowed-out place..." From the two countries US and Slovenia of such vastly different sizes, these poets, both influenced by such luminaries as Emily Dickinson and Marina Tsvetaeva, have carved out intimate spiritually enriching spaces where consciousness meets the sublime. Focusing on Kušar's view of Heraclitus as a teacher who "understood invisible strings are stronger than visible ones, "I will explore the thematic, literary and stylistic connections between these two literary stars, as well as some of their differences in how they cultivate a poetics of the invisible that illuminates the mysterious underworld of the human soul as it negotiates the political, philosophical and ethical realms of contemporary existence.

Keywords: Slovenian poetry / American poetry / comparative studies / Kušar, Meta / Valentine, Jean / poetics of the invisible / feminism

Noise abounds in the streets, in technology, in the media, in the political rhetoric. In a recent article "Disappearing Acts," Gal Beckerman in reviewing two new books on the value of invisibility and silence in our culture, notes that what is "unseen, undetected and overlooked" (20) is often where real meaning and power lie. Such invisible silences may act as an antidote or inner force against the "noise" that seems to grow louder, more insistent and pervasive in our time while saying less and less to our souls. Meta Kušar in a recent interview in The Bridge of Voices refers to Heraclitus as her teacher "who understood that the invisible strings are stronger than the visible ones" (Carlson and Jackson 78). It is through these strings that Kušar and American poet Jean Valentine's voices create a space as intimate and spiritually enriching as it is vast 
with larger concerns of community, humanity, existence. And while one writes in English and the other in Slovenian, both move invisible strings within and between readers to resonate at new registers.

Jean Valentine introduces her book Break the Glass with the epigraph by Lorine Neidecker: "A pencil/for a wing bone" (3), leading us to consider the way writing allows for transcendence. Meta Kušar begins her poem "Second Table" with a pencil that "lifts the soul, attach [ing] the poem to the invisible womb." For both the act of writing compels them to reach out of themselves and into the unknown source of creation.

Valentine begins an earlier book The Cradle of Real Life with "The Pen" that "writes by itself," and whose thought is

lying on the thought of the table

a bow lying across the strings

not moving

held (247)

In "Second Table" Kušar's pencil germinates the poem's lines into a living body: "When it springs to life, the pencil tip / lays a germ amid the lines." Kušar sees matter as spiritualized and poems as living nature, "a stalk / turning green" (Ljubljana 87).

For Valentine too, poetry is a living entity. She says in an interview: "My goal is to take out everything that doesn't feel alive. And to get to a place that has some depth to it. Certainly I'm always working with things that I don't understand with the unconscious, the invisible. And finding a way to translate it" (Break the Glass back jacket). In "Bury Your Money" from Shirt in Heaven, she writes, "Great captivities tap / in our sleep," though what such captivities are remain invisible in the material public world. Something confined but voracious within us knocks: "[G] reat famines bury the ear and the mouth, / though captivities cut parts away." To feel a sense of the divine we must "Be naked, John Cage said / Music is continuous, only listening is intermittent" (26).

We might view both poets as flowing-beneath-the-surface-of-culture, carrying their insights in deep images flecked with the surreal, creating a sense of being both grounded in time and eternal. Both subvert expected outcomes, reaching for the unknowable. They often come at this in different ways. Valentine's lyricism comes through terse often muted fragments. She allows for white spaces, silences and pauses in her arrangements, as though spreading the poem across the page like shell pieces that hold memories, music and other lives within each fragment. 
In "The Japanese Garden" from Break the Glass, Valentine looks at the Japanese garden with its precise number of wet green stones, bamboo and ferns that quickly becomes imagined as an underwater scene with the birds as fish. In the final lines she turns to the reader:

And you,

masked reader: the glance

of your underwater lamp,

your blackwater embrace-

not bought or sold. (13)

Maybe this scene is meant to estrange our perception of what is before our eyes. Maybe the reader, which includes herself, is the one both giving and receiving as a result of looking more deeply. The perception of being embraced by the strange or unseen holds enormous trust in the mystery that cannot be unpacked or made into a commodity. Kušar too estranges but often in a more direct emphatic tone:

Language senses depth

And the dark of a rose.

And a calm that doesn't prize honors.

If I get only a whiff of unity,

I drive misfortune away. (63)

Kušar feels her way more directly. While both employ different tones, they recall Emily Dickinson, not only in so far as the act of writing allows for spiritual revelation and rupture from social, literary and religious constraint, but also in their ambiguity. Stevie Edwards, in her article "A Room Without Men: Toward Outlining a Feminist Perspective," describes how an elliptical poetry may at times be a resistance to male dominated patriarchal poetry which has traditionally favored rationalism, explanation and grammar (57). As these two came of age at a time which did not explicitly explore the inner lives of women, both cultivate a poetic expression that both empowers and celebrates this intimate space that at times seems to resist or repel easy access.

Dickinson becomes a powerful under-voice for Kušar in her view of the spiritual force that is stronger than any human construct or system. As she writes in poem " 28 " from Ljubljana: 
Logic doesn't come first, though it eases things.

Somewhere between courage and worship

My learning breaks

Over the brim.

Although massive palaces pile up permanence for themselves,

Cold will crack them till they bleed. (59)

Spirit breaks through unapologetically. In poem " 75 " she evokes Dickinson on the shallowness and corruption of a worldly attention, but with a cutting tone:

It echoes down the corridor.

To win! To win

To clamor for fame!

One devastated vision. (109)

The poem itself goes on to focus on the female as giver of life that endures unrecognized as "this black moonlight does not dare honour the woman / calmly giving birth under the dome." What will restore us? She says in poem "76," "solitude will restore the rooms its desire," but wonders what a flower or vine such as ivy sees "when it climbs out of the grave?" (109)

Like Kušar, Valentine focuses on the force beneath the surface. In "Open" from Shirt in Heaven, she "lay[s] down under language" (20) and enters that liminal between death and birth. In that invisible under-space, the speaker is receptive. Only when language left, "the Comforter, came into the room," the blood and mouth "all buttoned away" as she says goodbye to all the "Makers of horses, books, clothes" (20), subverting the Christ figure as "King" in Dickinson's "I heard a Fly buzz-when I died- $-"(265)$.

I heard a Fly buzz-when I died-

The Stillness in the Room

Was like the Stillness in the Air-

Between the Heaves of Storm-

The Eyes around — had wrung them dry-

And Breaths were gathering firm

For that last Onset-when the King

Be witnessed-in the Room-

I willed my Keepsakes—Signed away

What portion of me be 
Assignable — and then it was

There interposed a Fly-

Valentine's whisper goes directly into the ear. In "Bardo" from Shirt in Heaven, she begins by addressing a homeless person. But when their eyes meet, it is as if this person morphs into her spiritual teacher, allowing her to remove all the coverings and enter the elemental.

You were picking through a trash bag,

taller than you.

Taking out anything worth something.

Our eyes met. I thought

What keeps us here? Two-legged?

You looked right through me. (18)

The word "bardo" (in Tibetan Buddhism) denotes the transitional state between death and rebirth, but as Sogyal Rinpoche tells us "bardos are occurring continuously throughout both life and death, and are junctures when the possibility of liberation, or enlightenment, is heightened" (11). A juncture is a point at which two bodies are joined. It is also a pause, a space allowing presence, clarity and compassion to penetrate.

Valentine is continually seeking such a space to counter the brutality of the world, natural or otherwise. In "The Just-Born Rabbits" from Break the Glass, she finds the furless newborns in the garden "huddled blind, translucent, hardly here." After a double stanza break, she writes matter-of-factly: "I called John (a farmer), and asked him what to do: // Put your boot on them. Now you've been there, / The mother will never come back." The poem ends with a paradox and acquiescence to the unknowable as well as another double stanza break to give pause and attention in a blank space before the holy: "-life from whom/death also springeth green / - thy leave to sleep (31). She goes from flat to psalm-like, not only as a way toward consolation, but also to illuminate further understanding of the wholeness of vision in this view of bardo as a paradox containing death in life and life in death.

The characters in Valentine's poems are often those vulnerable, misunderstood, hidden or lost in some way or other, sustained by unseen sources. In "The Helicopter," from Shirt in Heaven, note how the universe opens from "the little girl [...] crying, her mother, a girl herself, / [...] giving birth, [as] the forest dropped birdseeds of milk" (23). She compares the mother to the artist Joseph Cornell "who came to us empty-handed" (23), but whose boxes breathe the universe. Such 
further drawing from the deeper world is reminiscent of the image in Tomas Tranströmer's poem "Fire-Jottings," of how he with his lover, "milked the cosmos and survived" (171). She finds similar soul nourishment in Lucy, the ancient hominid whom she addressed in a sequence of poems at the end of Break this Glass. Lucy becomes a kind of soul mother "filling [her] center-hole / with bliss" (64), representative of one that transcends death to feed the hungering soul.

Valentine is a poet attuned to and nurtured by the view that most of reality is hidden from our senses. In The Physics of God, author Joseph Selbie quotes near-death researcher Kevin Williams in comparing reality to boxes: "There are many realms that take up the same space as the physical realm much like boxes within boxes. The physical realm is but one of the boxes in the hierarchy of boxes" (126). Valentine's poems often have the feel of not only a Cornell box but also a matryoshka doll with hidden realities nested inside.

While Valentine's language is muted and spare with elliptical images, Kušar stacks lines unbroken by white space to create, in Stanislava Repar's words, "associative labyrinths" (176) that convey a feisty defiance; she has a high-spirited ego, almost in opposition to the ostensibly ego-less surface of a Valentine poem. In her poem "Fortress" from This Hollowed-Out Place That Barely Exists, she compares love to a pair of tweezers probing matter. At the same time when such tweezers "grab hold of trash / they get bent," the idea being that the mind is corruptible depending on what it explores. But she will not "bow down to oppressors. / I'll push them away." Trash becomes an oppressor. When she proclaims, "Let God receive them! / Where does it say I have to do it alone?" (73), she leaves it to God in a voice that is both empowered by and accepting of a higher spiritual force, the fortress becoming the invisible.

In Kušar's work we might sense at times the influence of Tomaž Šalamun in both his image-layering and subversion, although Kušar's is a strong feminine voice that, as Repar notes, does not "hang on the climbing rope of 'man's investment' but is self-confident and disobedient ... focused on her own destiny" (177). Her layers accrete to summon the sublime underneath

to find the accomplice

combed

in this hollowed-out place

that barely exists. (Hollowed-Out Place 75) 
Valentine's layers are more unspoken as they too seek to uncover what was woman's history. In "He Says to me, Ireland" from The Door in the Mountain, Valentine acknowledges the void in recorded history as she says:

But I want those women's lives

rage constraint

The poems they burned

in their chimney-throats

The History

of the World Without Words

more than our silver or your gold art. (266)

Kušar views poetry as bread. The process of kneading, the word, which in English contains a wonderful double-meaning "needing or necessity" also represents the connective tissue between women and generations of women:

Like my mother and other women before her,

I knead dough slowly and want it to rise well.

I don't want to be rushed.

Even if deserted streets chilled me to the bone. (Ljubljana 105)

Kneading the dough is also questioning and knowing that "If my questions run dry, / What's really mine won't come to me" (105).

Kušar conflates the personal, historical, political and metaphysical in expressing the "smallness" of being ignored or passed over, a common plight of women throughout history.

I know the smallness

That a poem falls into when

No one bothers to see your fingers.

Or look you in the face!

Because they don't know why words exist. (61)

Her concern reaches further out into human destruction and survival as "a blind kangaroo hurling himself against the fence," to characterize the anger, desperation and helplessness against all forms of destruction the human inflicts on the world. For "Between Athens and Amsterdam lies I affliction" (107). And evil that is denied is eventually exposed, and in this way Kušar fears for beauty, and yet belief in the essential "dripping from the white mountains" is ever-present. Her ending on the color white acknowledges its paradoxical nature as being both blank and infi- 
nite with color, as well as symbolic of the one-ness or unity of all things. Perhaps this is the "white path down through the garden" (101).

Kušar's final poem in Ljubljana is prescient, if not tongue-in-cheek in the way it addresses the contemporary political moment in parablelike if not satiric terms of a nobleman and his estates being ruined by "nomads" who do not know about his tumultuous life. When the nobleman steps vigorously inside a monastery, she wonders at the nomads' lack of awareness. "Don't they know about the passageways between the walls and air?" resonates, as he is also the barbarian who "ruins all the ladies and their gifts." She draws from the passageway, the hidden pathway, to exclaim, "What a thought! / to link him with the remnants of the heavenly world" (111). In this way Kušar asserts her truth with bold irony.

Valentine feels a similar sense of injustice goes to the core of our being. Julie Carr in an essay on Valentine ("On Saying No: Valentine and Dickinson Break the Glass") notes that "Valentine's outrage emerges from her awareness that oppression and violence do not only insult and injure the body, they also harm the spirit, and are thus insults levied directly at God" (229).

Both poets also feel a connection to Marina Tsvetaeva, who felt many souls resided in her, and whom in reading we might find "that spiritual forces compete in every line she ever wrote" (xi). Tsvetaeva called her desk transcendent instrument (53) akin to Valentine's pen and Kušar's table. Kaminsky, in his afterword to Dark Elderberry Branch, mentions that Tsvetaeva had "a frenzied wish to become lost" (35). That sense of being lost is also one of being lost in languageTsvetaeva questioned her native language "What is one's native language? ... [P] oets speak in enigma—as children do ... slants, gaps ... empty pockets" (37). Tsvetaeva wrote out of unimaginable hardship and loss even as she yearned for artistic expression, finding spiritual meaning in the ordinary: "To know the spirit is my beloved" (3). At the same time, she blesses her daily labor, sleep, night,

And the coat, your coat, my coat,

half dust, half holes.

And I bless the peace

in a stranger's house-the bread in a stranger's oven. (3)

To bless the coat is to bless what protects and keeps us warm. Only it has holes, which she blesses as well. And peace not in her house, but in a stranger's house as warm bread, an image that places nourishment in 
the warmth of stranger. For Tsvetaeva, estrangement and ruin can also lead to connection.

This blessing of a stranger's intimate space recalls Valentine's capacity for empathy extending to the heart's core, where there are no divisions. For example, in this one from Shirt in Heaven addressed to Tsvetaeva, "Her last year" where Valentine bids Tsvetaeva to rest her mouth, music, her "walking around" and to drink and eat, even while Valentine sees her eating stones, bones, mud and light. First, Valentine doesn't recognize anything, "Not a sign, a cut, a knife, a dark wood, a net." After a double stanza break she writes the opposite, "I recognize everything. / The sign, the cut, the knife, / the dark wood, the net." (9). In the imaginative act, Valentine becomes the other, and boundaries dissolve. And this echoes with Kušar's call for oneness with a wider lens as in poem " 50 " from Ljubljana:

Black masters check your heart

In the same way white masters do.

They line us up carefully.

There is just one voice calling. Here and there. (83)

Such is the reaching out of one into otherness and unity as she writes in poem " 58 ": "Who nowadays would still build a hearth that does not end at the threshold? / Who comes to my feast of all colours and cultures?" The poem goes from stewing blueberries to horses enduring in battle because "While Easter buns are sizzling in the oven, / death gives off a pungent smell ... cut[ting] through the months. The length of all things." It is as if the poem moves through the world and her heart at the same time, "only the heart / has it his own way, because blood is visionary, / when not poisoned" (91).

For Valentine, real vision lies in the view that what is essential is the presence between us, the relation. That is the crucial encounter, drawing from Martin Buber's view, "All actual life is encounter" (62), ${ }^{1}$ and that rather than holding love, we dwell in our love as a cosmic force (66). Valentine continually reckons with such a force on multiple levels. She addresses the "god of empty rooms, god of / one unable to speak" (Shirt 10) for Paul Celan. She knows she cannot "hold the finch who flew into the window" (11), for it flies into Osip and Nadezheda Mandelstam's faces. She casts out of herself into "speechless rising and setting" feeling with another: "Do I concern you? Am I there?" (12). Her empathy is personal and out of her own suffering her words seem

\footnotetext{
${ }^{1}$ This is also the epigraph to Valentine's The Cradle of Real Life.
} 
to stream from heart-blood toward another as John Clare in his madness and loneliness with

love and nowhere for it

to go but your

sweet open eye to the wounded

eye of the beloved

then the bony aloneness (16)

Writing in lower caps with no punctuation, she enacts with tenderness and humility entrance into another's pain.

In conclusion, while their form and language may differ: Valentine offering a more open arrangement of spaces and silences, understated language as well as elliptical imagery where the self may lay low, and Kušar moving in stacks of lines with abrupt imagistic shifts and a more direct, emphatic voice to sound the vitality and potency of her concerns; both Valentine and Kušar share a profound understanding of spiritual forces at the heart of existence, which they seek to illuminate. Both recall at times Dickinson and Tsvetaeva, cultivating ambiguities that resist easy access, while celebrating intimate albeit cosmic spaces of enlarged vision and heart. And both perceive the underlying unity that we are all one sounding through unseen but connected strings. Neither Valentine nor Kušar amplify their voice in their respective language. Rather, they embrace with verve, vision and grace what Thomas Merton sought, a "genuine and deep communication," (243) in order that we may find sustenance for our souls that might otherwise be lost in the noise. For here "The door is fallen down / inside my open body / where all the worlds touch" (Little Boat 11).

\section{WORKS CITED}

Beckerman, Gal. "Disappearing Acts.” New York Times Book Review 24.2 (2019). 20. Buber Martin. I and Thou. Trans. Walter Kaufman. New York: Scribner, 1970.

Carlson, Barbara Siegel, and Richard Jackson, eds. A Bridge of Voices. Chattanooga, TN: Kindle, 2017.

Carr, Julie. "On Saying No: Valentine and Dickinson Break the Glass." Jean Valentine This World Company. Kazim Ali and John Hoppenthaler, eds. Ann Arbor: University of Michigan Press, 2012. 223-223.

Dickinson, Emily. Collected Poems. Ed. by R. W. Franklin. Cambridge, MA: Harvard University Press, 1999.

Edwards, Stevie. “A Room Without Men: Toward Outlining a Feminist Perspective." The Writer's Chronicle February (2019). 54-62.

Kušar, Meta. This Hollowed-Out-Place that Barely Exists. Featured tran. chapbook. Mid-American Review (2016). 67-83. 
- - -. Ljubljana. Tran. Ana Jelnikar and Stephen Watts. Todmorden: Arc, 2010.

Merton, Thomas. Seeds of Destruction. New York: Farrar, Straus and Giroux, 1964.

Repar, Stanislava Chrobakova. "Three Times on the Royal Road." The Voice in the

Body. Ljubljana: Slovene Writers Association, 2005. 173-192.

Rinpoche, Sogyal. Tibetan Book of Living and Dying. New York: HarperCollins, 1993.

Selbie, Joseph. The Physics of God. Newburyport, MA: New Page Books, 2018.

Valentine, Jean. Shirt in Heaven. Port Townsend, WA: Copper Canyon Press, 2015.

- - - Break the Glass. Port Townsend, WA: Copper Canyon, 2010.

- - - Little Boat. Middletown, CT: Weslyan University Press, 2007.

- - - The Door in the Mountain. Middletown, CT: Weslyan University Press, 2004.

Tranströmer, Tomas. The Great Enigma. Tran. Robin Fulton, New York: New Directions, 2006.

Tsvetaeva, Marina. Dark Elderberry Branch. A Reading by Ilya Kaminsky and Jean Valentine. Farmington, ME: Alice James Books, 2012.

\section{Nevidne vezi: proučevanje povezav med poezijo Jean Valentine in Mete Kušar}

Ključne besede: slovenska poezija / ameriška poezija / primerjalne študije / Kušar, Meta / Valentine, Jean / poetika nevidnega / feminizem

Epigraf "A pencil / for a wing bone» (»Svinčnik / za lopatico») v pesniški zbirki Break the Glass pesnice Jean Valentine (gre za verz Lorine Neidecker) spodbuja k razmisleku o tem, kako pisanje omogoča transcendenco. Podobno v svojem delu Meta Kušar razčeše zvezde z glavnikom in nato najde "zaveznika / počesanega / v tej votli deželi«. Pesnici, ki prihajata iz dveh po velikosti tako različnih držav, kot sta ZDA in Slovenija, in na kateri so vplivale ikone, kot sta Emily Dickinson in Marina Cvetajeva, sta ustvarili intimne in duhovno oplajajoče prostore, v katerih se zavest sreča s sublimnostjo. Avtorica se osredotoča na pogled Kušarjeve, da je Heraklit učitelj, ki »je razumel, da so nevidne vezi močnejše od vidnih", ter proučuje tematske, literarne in slogovne povezave med tema dvema literarnima zvezdama, pa tudi nekatere razlike pri ustvarjanju poetike nevidnega, ki osvetljuje skrivnostno podzemlje človeške duše med obvladovanjem politične, filozofske in etične sfere sodobnega obstoja.

1.04 Strokovni članek / Professional article

UDK 821.163.6.09-1Kušar M.

821.111(73).09-1Valentine J.

D0I: https://doi.org/10.3986/pkn.v42.i3.08 